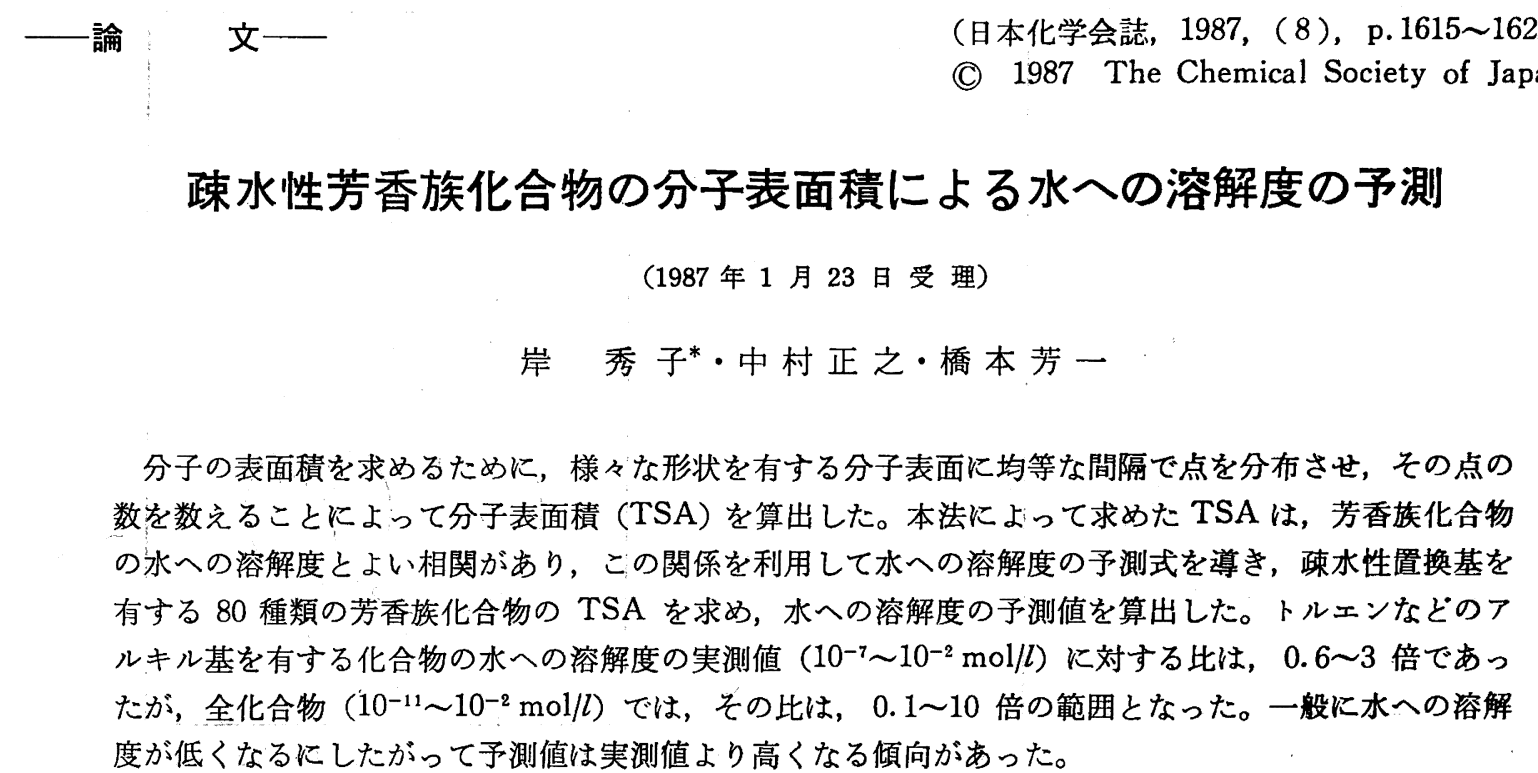

\section{1 緒言}

化学物質は，製造，利用あるいは廃率の過程において環境中に 放出され，地球上の水圈，地圏扣よび大気圈の各コンパートメン トに様々な污染を誘発している。これらの化学物質の環境におけ る挙動を把握するために, 水への溶解度, 土壤吸着平衡定数, 生 物濃縮係数，水溶液加らの蒸発速度定数，加水分解速度定数，解 離定数などの物理化学定数を測定して実験室的に環境における現 象を予測しよ5とする研究が近年盛んに行なわれている。これら の物理化学定数の中でも, 水への溶解度は, 他の物理化学定数と 関連が深く，とくに重要な定数である。

水への溶解度は, 分子表面積 (Total Surface Area, 以下 TSA と略記する）と負の相関があることが知られておりり2)，こ の関係を利用して水への溶解度の概略値を算出することができ る。

TSA は，分子を構成する各原子の van der Waals 半径, 原 子間距離および結合角によって幾何学的に求められ，得られた TSA と融点とを組み合わせることによって水への溶解度が予測 できる。しかしながら、これまでに TSA の算定方法に関する詳 しい報告はなく，新たな物質について TSA を求めて水への溶解 度を予測しよらとする場合には，TSA の計算方法を開発しなけ ればならない。一方，TSA と水への溶解度との相関関係につい ていくつかの報告はあるが，同一種類の膡換基を有する化合物の 間で調ベられたものであり，その相関式は，アルコール類 ${ }^{8)}$, ポ 1リクロロビフェニル（以下 $\mathrm{PCB}^{4)}$ と略する）八ロゲン化ベンゼ

度応義塾大学理工学部応用化学科, 223 横浜 市港北区日 吉

1) S. H. Yalkowsky, R. J. Orr, S. C. Valvani, Ind. Eng. Chem. Fundam., 18, 351(1979).

2) S. H. Yalkowsky, S.C. Valvani, J. Chem. Eng. Data, 24, 127(1979).

3) S.S. Lande, S. Banerge, Chemosphere, 10, 751(1981).

4) D. Mackey, R. Mascaren, W. Y. Shiu, ibid., 9, 257 (1980).
ン゙など個々に示されている。

そこで本研究では，乱数を用いない Monte Carlo 法の応用に よってTSA を算出する方法を開発し，この方法によって芳香族 化合物の TSA を求めた。さらにTSA と水への溶解度との相関 関係を調へ，得られた相関式を予測式として，81 種類の芳香族 化合物の TSA を算出して，これらの水への容解度の予饈值を求 めた。この予測值と実測値あるいは文献值とを比較して，TSA による水への溶解度の予測の可能性について検討した。

\section{2 理論}

\subsection{Monte Carlo 法による分子表面㮴の計算}

Monte Carlo 法は，通常乱数を発生して標本を抽出し，その 標本が目的とする現象を満足している場合には，その現象を 1 力 ウントとして数える。この操作を反復して目的とする現象の相対 頻度を求め，その確率から全体の現象を把握する方法である。こ こでは，この方法を応用して分子表面積を求める。磦本の抽出に は乱数を使用せず，分子を構成する原子を球と仮定して，その表 面に均一に点を与え，その与えられた各点について，隣接する原 子の内部に入らない位置にある点であるかどらかを判定して，分 子表面にある点の数のみを数える。半径 $r(\AA)$ の原子表面に $N$ 個 の点を与えたとき，隣接する原子の内部にない点の数が $C$ 個あっ たとすると，原子球表面積 $4 \pi r^{2}$ の $C / N$ が隣接する原子の内部 に入らないその原子の表面積 $A\left(\AA^{2}\right)$ となる。これは式(1)によ って求まる。

$$
A=4 \pi r^{2} \cdot C / N
$$

原子表面の点に偏りがなければ，表面積の真値 $A_{\text {real }}$ は $\lim _{N \rightarrow \infty} A=A_{\text {real }}$ である。

\section{2 原子表面に均一に点を与える方法}

原子の表面に均一に点を分布させるために，原子の中心座標 $O_{0}\left(x_{0}, y_{0}, z_{0}\right)$ とし， $z$ 軸を中心に $z=0$ を通る $X Y$ 平面までを $n$ 等分し，その分割された角度を $\Delta \psi=180 / n$ とする。 $z$ 軸から 分割された $i$ 番目の角度 $\psi_{\mathrm{t}}$ は， $\phi_{1}=\Delta \psi \cdot i$ で表わされる（四 1 


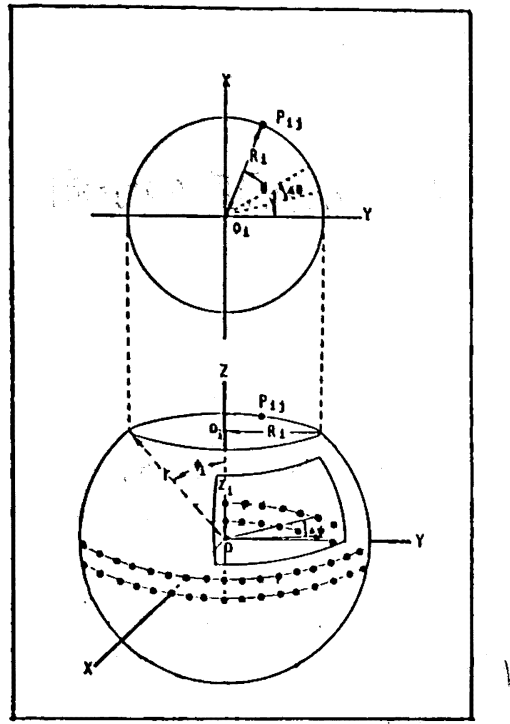

Fig. 1 Equidistant points on the surface of the atom

$\Delta \psi=180 / n, \phi_{1}=\Delta \psi \cdot i, \quad(i=0 \sim n-1)$

$O_{\mathrm{i}}$ : Sectional midpoint $\left(z=r \cdot \cos \phi_{\mathrm{i}}\right)$

$\Delta \theta=360 / n, \quad \theta_{\mathrm{i}}=\Delta \theta \cdot j+\theta_{0},\left(j=0 \sim n_{\mathrm{j}}-1\right)$

$R=r \sin \phi_{\mathrm{i}}, P_{\mathrm{ij}}$ : a dot on a atom

の側面図)。つぎに原子を $z=r \cos \psi_{1}$ で， $X Y$ 平面に平行な面 で切ると, その断面は, 半径 $R=r \sin \psi_{i}$ の円となり, その円周 は, $2 \pi R=2 \pi\left(r \sin \psi_{\mathrm{i}}\right)$ で表わされる(図 1 の断面図)。この円 周上に等間隔に $n_{1}$ 個の点を与えると, 各点間の 1 区間の角度 $\Delta \theta=360 / n_{1}$ となる。ここで，それぞれの $z=r \cos \psi_{1}$ で切られ た $X Y$ 面の断面の円周は， $\psi_{1}$ が增大するにしたがい大きくな り，円周に与える点と点の間隔を等しくすると，点の数は $\sin \psi_{1}$ に比例する。またこの断面の円周上に与えられた $j$ 番目の点 $P_{i j}$ の座標を $\left(x_{P_{\mathrm{ij}}}, y_{\mathrm{P}_{\mathrm{i}}}, z_{\mathrm{P}_{\mathrm{ij}}}\right)$ とすると, この点は, 式(2)で 表わされる。

$$
\left.\begin{array}{l}
x_{\mathrm{P}_{\mathrm{ij}}}=r \sin \psi_{\mathrm{i}} \cdot \cos \theta_{\mathrm{J}}+x_{0} \\
y_{\mathrm{P}_{\mathrm{ij}}}=r \sin \psi_{\mathrm{i}} \cdot \sin \theta_{\mathrm{j}}+y_{0} \\
\boldsymbol{z}_{\mathrm{P}_{\mathrm{i}} \mathrm{P}}=r \cos \psi_{\mathrm{i}}+z_{0}
\end{array}\right\}
$$

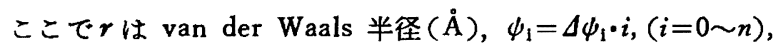
また， $\theta_{\mathrm{j}}$ は $X Y$ 平面上の角度 $\theta_{\mathrm{J}}=\Delta \theta \cdot j+\theta_{\mathrm{ol}}\left(j=0 \sim n_{1}-1\right.$, $\theta_{\text {o1 }}$ : 初期角度) であり， $x_{0}, y_{0}$ および $z_{0}$ は，原子の中心座標 $O_{0}$ である。

\section{3 分子表面に位䈯する点の判定}

分子を構成する $I$ 番目の原子の表面に与えられた点 $P_{\mathrm{I}}$ が，隣 接するすべての原子の内部に位置しないことが判定されたとき， その点は，分子表面にある点として数える。

$I$ 番目の原子に隣接する原子を $J$ とすると，その表面を表わす 方程式は，式( 3 )に示すとおりである。

$$
\left(x-x_{\mathrm{J}}\right)^{2}+\left(y-y_{\mathrm{J}}\right)^{2}+\left(z-z_{\mathrm{J}}\right)^{2}-r_{\mathrm{J}}^{2}=0
$$

式( 3 )に $I$ 番目の原子表面にある点 $P_{\mathrm{I}}\left(x_{1}, y_{1}, z_{\mathrm{I}}\right)$ を代入して 得られた式 (4)によって, 点 $P_{1}$ が $J$ 番目の原子の内部に位膡し

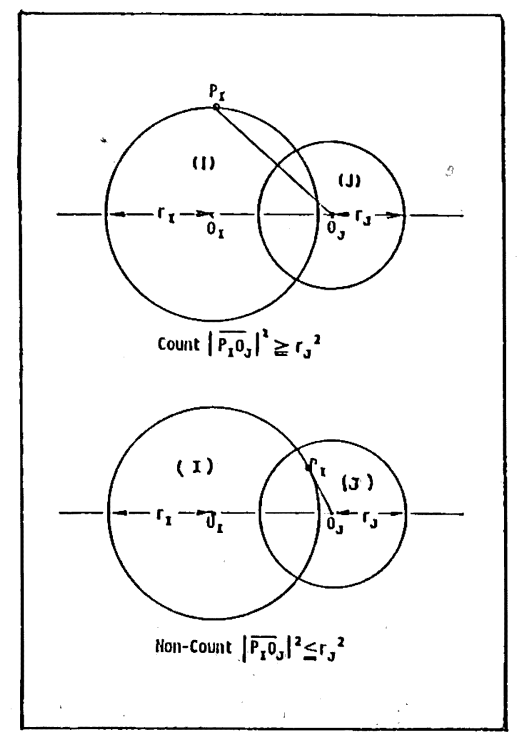

Fig. 2 Geometry of molecular surface determination

ないかを判定する。

$$
\left(x_{\mathrm{I}}-x_{\mathrm{J}}\right)^{2}+\left(y_{\mathrm{I}}-y_{\mathrm{J}}\right)^{2}+\left(z_{\mathrm{I}}-z_{\mathrm{J}}\right)^{2}-r_{\mathrm{J}}^{2} \geqq 0
$$

この条件が満足されるとさ，点 $P_{I}$ を数える（四 2)。式(4) が满足されない点は, 図 2 に示すように $I$ 番目の原子上にある点 $P_{I}$ が $J$ 番目の原子の内部に位置するものであり，この場合には 数えない。 $I$ 番目の原子表面上に与えた点の数を $N_{\mathrm{I}}$, 式(4)が 満足された点の数が $C_{\mathrm{I}}$ であるとすると, 原子表面に位置する点 の数の割合は $C_{\mathrm{I}} / N_{\mathrm{I}}$ となり，I番目の原子の TSA は，式(1) によって求めることができる。同様にして, 分子を構成する原子 のそれぞれについて分子表面積を算出して，すべての原子の原子 表面積の総和を求める。この值が分子表面積 (TSA) である。

\section{4 原子表面上の各点の座標}

分子を構成する各原子表面に与えられた座標は，各原子の原子 半径 (van der Waals 半径), 原子間距離拈よび原子結合角によ って求める。その方法は, 分子を構成する各原子に $1,2,3, \cdots I$ …と番号を付け，各原子の中心の直交座標上の位置を原子間距離 と結合角によって決める。

1 番目の原子の中心を原点 $O_{1}\left(x_{1_{0}}, y_{1_{0}}, z_{1_{0}}\right)$ とし，2番目の原 子の中心 $O_{2}\left(x_{2_{0}}, y_{2_{0}}, z_{2_{0}}\right)$ は $Z$ 軸上に直き，その位值は 1 番目の 原子と 2 番目の原子間距離によって決める。3 番目の原子の中心 $O_{3}\left(x_{3_{0}}, y_{3_{0}}, z_{3_{0}}\right)$ は, $X Z$ 平面上に置き， その位置は 2 番目と 3 番 目の原子の原子間距離と原子結合角 $\left(\angle \mathrm{O}_{1} \mathrm{O}_{2} \mathrm{O}_{3}\right)$ によって決ま る。 4 番目の原子の中心 $O_{4}\left(x_{4_{0}}, y_{4_{0}}, z_{4_{0}}\right)$ は， 3 番目之 4 番目の 原子間距離と結合角 $\left(\angle \mathrm{O}_{2} \mathrm{O}_{3} \mathrm{O}_{4}\right)$ によって決まるが，ここで取 り上げた化合物はベンゼン環を有するものであり，分子は平面構 造であるから，各原子の中心は， $X Z$ 平面上に位直し，その結合 角は $120^{\circ}$ となる。

以上のよ5にして順次各原子の中心座標 $\left(x_{10}, y_{\mathrm{IO}}, z_{\mathrm{IO}}\right)$ を決定 する。つぎにさきの2.1において与えられた $I$ 番目の原子上のそ れぞれの点 $P_{\mathrm{I}}\left(x_{\mathrm{I}}, y_{\mathrm{I}}, z_{\mathrm{I}}\right)$ を極座標 $(r, \theta, \psi)$ として表わすには, 式(2)の $x_{0}, y_{0}, z_{0}$ IV各原子の中心座標 $O_{\mathrm{I}}\left(x_{10}, y_{\mathrm{IO}}, z_{\mathrm{IO}}\right)$ を代入 


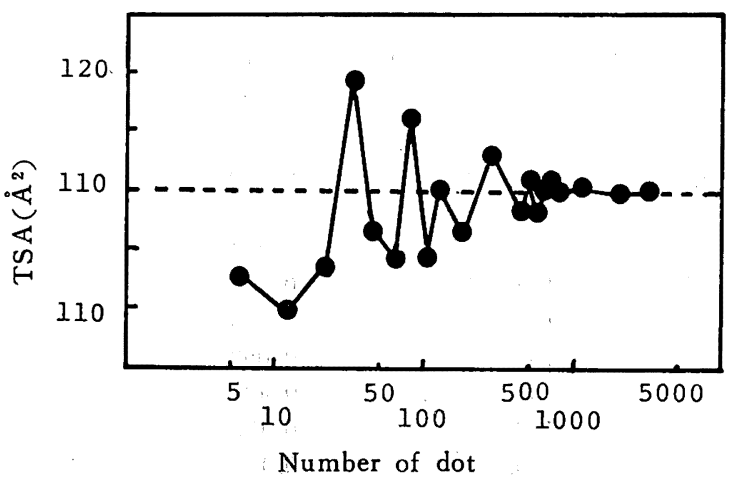

Fig. 3 Variation of the calculated total surface area with the number of dots

して求める。この方法によって分子を構成する原子 $1,2,3, \cdots I$ ‥の中心座標怙よび各原子の表面上に与えた点の座標を決定する ことができる。ただし、すでに述べたように1番目の原子の原点 の座標 $O_{10}$ は, 分子全体の直交座標の原点である。

\section{5 原子表面に与える点の数の決定}

原子表面上に与える点の数が多いほど TSA は一定値に収束す る。ベンゼンの場合，一つの原子表面に 20000 個以上の点を与之 ると, TSA は 109.9( $\left.\AA^{2}\right)$ となる。この值を真値と仮定すると, 点の数 510 個を与えて得られた TSA の值 $110\left(\AA^{2}\right)$ との誤差率 $\left.{ }^{5}\right)$ は， $1.0(\%)$ となり，732 個とした場合には，その誤差率は，1.0 （\%)以下となる。点の数が増加するにしたがってTSA の変動が 少なくなり真值に収束する（四 3 ）。同様に，ビフェニル，へキ サクロロベンゼンおよびピレンについても，点の数を 6〜3000ま で変化させて TSA の計算値の变動を調べた結果, 図 4 に示すと おり， 1 個の原子表面に 3000 個の点を与えて得られたTSA に くらべ, 点の数 510 個の誤差率は, ビフェニル $1.00(\%)$, へキ サクロロベンゼン 0.42(\%)，ピレン 0.91(\%)となった。また， 732 個の点を与えた場合には，各物質の誤差率は，0.36，0.22 拧 よび $0.13(\%)$ となり，点の数の增加とともに誤差率は低くなる。

このように，原子表面に与える点の数の增加にともない， TSA の計算值の変動が少なくなり，ついには一定值に収束する が, TSA の計算に要するコンピューター專有時間は，点の数の 增加に比例して長くなる。

ここで得られたTSA は，水への溶解度の実測値と相関性が高 く, 両者の相関式によって水への溶解度を予測する上で氷への溶 解度の実測值の变動が $3 \%$ 程度であるので, TSA の計算値の変 動も一応 $3 \%$ 以下となれば満足できるものと考える。そこで, Monte Carlo 法によって分子表面積を推定するためには，一つ の原子表面上に 510 個の点を与えればよい結論になる。この条件 では，たとえばへキサクロロベンゼンあるいは PCB 程度の化合 物の TSA は，通常のパーソナルコンピューターによって 10 分 間程度で計算することができる。

\section{3 実験}

水への溶㑇度の測定は，测定対象物質と水を $1: 100(\mathrm{w} / \mathrm{w})$ の

5）誤差率 $=1 ー \mid(510$ の点を与光て求めた $\mathrm{TSA} / 3000$ 個以上 の点を与えて求めた TSA $) \mid \times 100(\%)$.

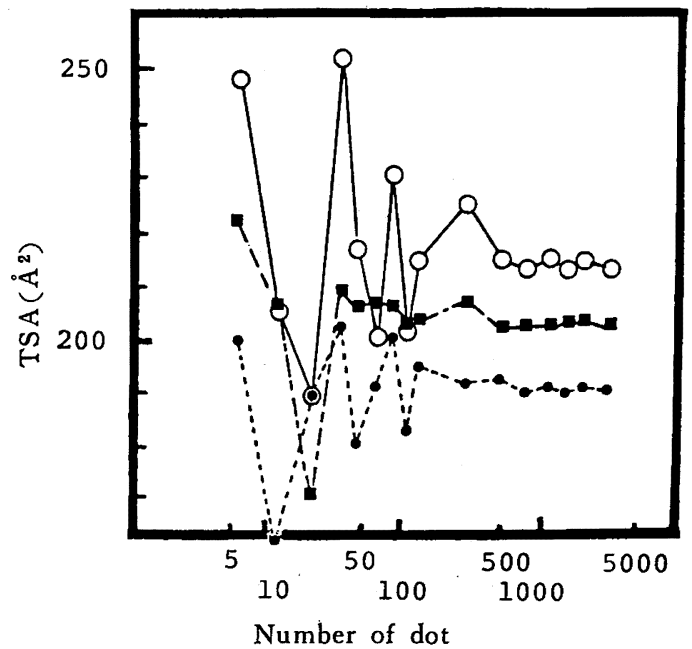

Fig. 4 Relationships between the number of dots and the calculated total surface area

-O-O- : Pyrene,

- : : Biphenyl,

- - : Hexachlorobenzene

割合でフラスコに入れ，50C に 30 分間たもったのち，5分間か きまぜ, 測定温度の恒温槽中に 48 時間静置して, この溶液の上 澄みをガラス織維製汇紙を用いて沪過し，沪液の濃度を測定して 水への溶解度の概略值を求めた。つぎにこの概略值の 100 倍に相 当吉る濃度になるよらに測定対象物質と水をフラスコに入れ, 測 定温度で 24 時間かきまぜたのち，48時間静置して，上澄みをガ ラス 織維製沪紙を用いて沪過し，その沪液濃度を測定して水へ の溶解度 $S(\mathrm{~mol} / l)$ を求めた。この場合, 水への溶解度の概略值 が $10^{-3} \mathrm{~g} / l$ 以上の物質では，結晶を直接水に投入したが，10-8 $\mathrm{g} / l$ 以下の物質では，結晶をガラスビーズにコーティングしたる のを用いて飽和水溶液を調製して，その濃度を測定して求め だ)。

飽和水溶液中の測定対象物質の濃度は, シクロヘキサン, ベン ゼンあるいはへキサンで抽出したのち, 吸光光度計（日本分光 製，UNIDEC-1）あるいは GC-ECD（島津製作所製 GC-8 A) を用いて分析をした。

\section{4 結果と考察}

\subsection{TSA の計算値の評価}

本法により求めた TSA の值を検証するために, すでに Yalkowsky ${ }^{12)}$ らによって計算されている值との此較を表 1 に示し た。結果は，文献值との差が $-0.39 〜 1.34 \%$ であり，原子表面 に 510 個の点を与えて得られたTSA の計算値は，ほぼ満足でき る值であると考える。

\subsection{TSA と水への溶解度との相関性}

TSA と水への溶解度 $S$ との相関式は，水への溶解度の予测式 とすることも可能である。ここでは，表 2 に示したクロロベンゼ ン誘導体の $\log S$ と TSA との相関関係を四 5 に示した。液体 物質であるベンゼン, クロロベンゼン, o-ジク口ロベンゼン,

6) Y. Hashimoto, K. Tokura, K. Ozaki, W. M. J. Strachan, Chemosphere, 11, 991(1982). 
Table 1 Comparison of calculated values with literature values of TSA

\begin{tabular}{|c|c|c|c|}
\hline Chemicals & $\begin{array}{r}\text { Calculated TSA } \\
\left(\AA^{2}\right)\end{array}$ & $\begin{array}{r}\text { Literature } \\
\left(\AA^{2}\right)\end{array}$ & $\begin{array}{c}\text { Error }^{c)} \\
(\%)\end{array}$ \\
\hline Benzene & 111.3 & $109.5^{a)}$ & 0.457 \\
\hline Chlorobenzene & 127.9 & $127.1^{a)}$ & 0.629 \\
\hline$o$-Dichlorobenzene & 143.3 & $142.7^{a)}$ & 0.420 \\
\hline$m$-Dichlorobenzene & 145.4 & 144. $7^{a)}$ & 0.484 \\
\hline$p$-Dichlorobenzene & 144. 9 & 144. $7^{a)}$ & 0.138 \\
\hline 1,2,3-Trichlorobenzene & 158. 7 & 158. $3^{a)}$ & 0.253 \\
\hline $1,2,4$-Trichlorobenzene & 160.3 & 160. $2^{a)}$ & 0.062 \\
\hline 1,3,5-Trichlorobenzene & 162.9 & 162. $2^{a)}$ & 0.432 \\
\hline 1,2,3,4-Tetrachlorobenzene & 173.5 & 173. $8^{a)}$ & -0.173 \\
\hline 1,2,3,5-Tetrachlorobenzene & 176.1 & 175. $\left.8^{a}\right)$ & 0.171 \\
\hline $1,2,4,5$-Tetrachlorobenzene & 175.7 & 175. $8^{a)}$ & -0.057 \\
\hline Pentachlorobenzene - & 188. 9 & 189. $4^{a)}$ & -0.264 \\
\hline Hexachlorobenzene & 202.2 & 203. $0^{a)}$ & -0.394 \\
\hline Naphthalene & 157.4 & $155.8^{b)}$ & 1. 027 \\
\hline Phenanthrene & 200. 2 & 198. $\left.0^{b}\right)$ & 1. 111 \\
\hline Anthracene & 204.9 & $202.2^{b)}$ & 1. 325 \\
\hline Pyrene & 215.8 & 213. $0^{b)}$ & 1. 314 \\
\hline \multicolumn{4}{|l|}{ a) Ref. 1). } \\
\hline \multicolumn{4}{|l|}{ b) Ref. 2). } \\
\hline \multicolumn{4}{|c|}{ c) Error $=[1-($ Literature value $/$ Calculated value $)] \times 100(\%)$. } \\
\hline
\end{tabular}

Table 2 Properties of chlorobenzenes

\begin{tabular}{lcccc}
\multicolumn{1}{c}{ Chemicals } & $\begin{array}{c}\mathrm{mp} \\
\left({ }^{\circ} \mathrm{C}\right)\end{array}$ & $\begin{array}{c}\text { TSA } \\
\left(\AA^{2}\right)\end{array}$ & $\log S a)$ & $(\log S)_{\mathrm{mp}}{ }^{b)}$ \\
\hline Benzene & 5.5 & 111.0 & -1.69 & -1.69 \\
Chlorobenzene & -45.6 & 127.9 & -2.37 & -2.37 \\
o-Dichlorobenzene & -17 & 143.3 & -3.02 & -3.02 \\
$m$-Dichlorobenzene & -24.4 & 145.4 & -3.10 & -3.10 \\
p-Dichlorobenzene & 53.1 & 144.9 & -3.52 & -3.19 \\
1,2,3-Trichlorobenzene & 52.6 & 158.7 & -4.11 & -3.78 \\
1,2,4-Trichlorobenzene & 17.0 & 160.3 & -3.71 & -3.71 \\
1,3,5-Trichlorobenzene & 63.4 & 162.9 & -4.62 & -4.18 \\
1,2,3,4-Tetrachlorobenzene & 47.5 & 173.5 & -4.80 & -4.52 \\
1,2,3, 5-Tetrachlorobenzene & 54.5 & 176.1 & -5.00 & -4.65 \\
1, 2, 4, 5-Tetrachlorobenzene & 140 & 175.7 & -5.84 & -4.63 \\
Pentachlorobenzene & 86 & 188.9 & -6.00 & -5.33 \\
Hexachlorobenzene & 230 & 202.2 & -7.69 & -5.57
\end{tabular}

a) $S$ : Solubility $(\mathrm{mol} / l)$.

b) $(\log S)_{\mathrm{mp}}=\log S+0.0101 \times(\mathrm{mp}-20)$.

m-ジクロロベンゼン, 1,2,4-トリクロロベンゼンの回㷌直線は, 固体物質である $p$-ジクロロペンゼン，1,2,3-トリクロロベンゼ ソ，1，3，5-トリクロロペンゼンなどのそれにくらべて勾配がゆる やかである。これは，固体物質が液体物質にくらべて分子間力が 強く，溶媒中に拡散しにくいためであると考えられる。

そこで，固体物質の溶解度を融解エントロピーと融点との積に よって補正し7)，この補正した固体物質の水への溶解度の対数 値, 融点補正溶解度 $(\log S)_{\mathrm{mp}}$ と TSA との相関性を調べた。 結果は，因6および式(5)に示すとおり，固体物質および液体物 質の区別なく，相関性の高い直線関係が得られた。

$(\log S)_{\mathrm{mp}}=3.401-0.0454$ TSA, $\quad r=-0.995, n=13$

7) S. H. Yalkowsky, Ind. Eng. Chem. Fundam., 18, 108(1979).

$$
\begin{aligned}
& (\log S)_{\mathrm{mp}} \text { : 融点補正溶解度 } \\
& \text { TSA：分子表面積 }\left(\AA^{2}\right)
\end{aligned}
$$

また，融点補正溶解度と水への溶解度との関係は，式(6)によ って表わされる?。

$$
(\log S)_{\mathrm{mp}}=\log S+0.0101(\mathrm{mp}-20)
$$

$\log S:$ 水への溶解度 $(\mathrm{mol} / l)$ の対数值

$\mathrm{mp}$ ：測定温度に扣いて固体物質であるものの融点

式 (5)によってペンゼンのクロロ曡換体の水への容解度の予測 をする場合には，この式の相関俰数は一0.995 であり，笑测值と 大差ない值が求まるであろらが，芳香族化合物全般について，同 様な結果が得られるとは考えられない。

そこで表 3 に示した 17 種類の芳香族化合物のTSA および $(\log S)_{\mathrm{mp}}$ を算出し，図6 と同様に $(\log S)_{\mathrm{mp}}$ と TSA の 


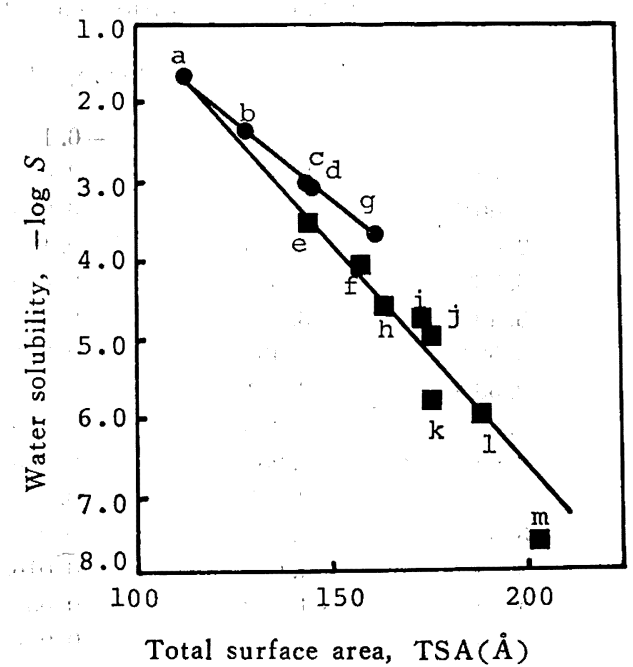

Fig. 5, Relationship between total surface area and water solubility:

:Liquid, $\square$ : Solid

a : Benzene, b : Chlorobenzene,

c : $o$-Dichlorobenzene, d : $m$-Dichlorobenzene,

e : $p$-Dichlorobenzene, f : 1,2,3-Trichlorobenzene,

g: 1,2,4-Trichlorobenzene,

$\mathrm{h}: 1,3,5$-Trichlorobenzene,

i : $1,2,3,4$-Tetrachlorobenzene,

j: $: 1,2,3,5$-Tetrachlorobenzene,

$\mathrm{k}: 1,2,4,5$-Tetrachrolobenzene,

m : Pentachlorobenzene, $\mathrm{n}$ : Hexachlorobenzene

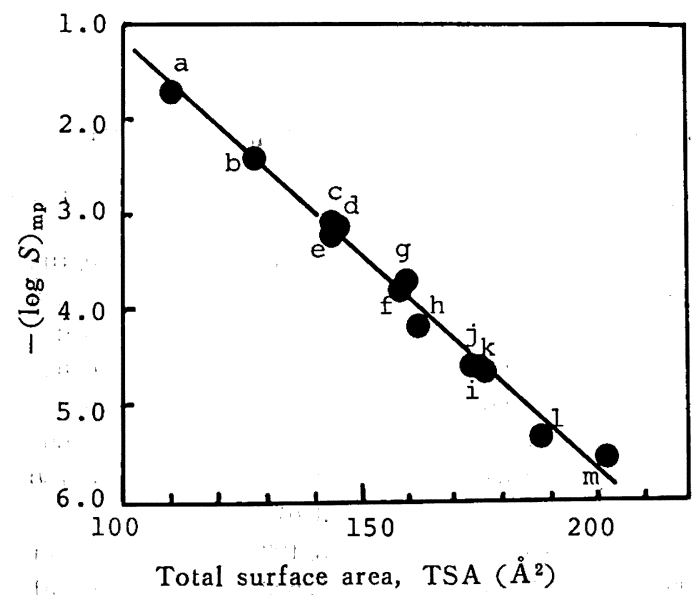

Fig. 6 Relationship between TSA and water solubility

$\mathrm{a}$ : Benzene, $\mathrm{b}$ : Chlorobenzene,

c : o-Dichlorobenzene, d : $m$-Dichlorobenzene,

e : p-Dichlorobenzene, f : 1,2,3-Trichlorobenzene,

$\mathrm{g}: \mathrm{1}, 2,4$-Trichlorobenzene,

h : 1, 3, 5-Trichlorobenzene,

i : 1,2,3,4-Tetrachlorobenzene,

$\mathrm{j}: 1,2,3,5$-Tetrachlorobenzene,

k : 1, 2, 4, 5-Tetrachlorobenzene,

1 : Pentachlorobenzene, $\mathrm{m}$ : Hexachlorobenzene

$(\log S)_{\mathrm{mp}}=\log S+0.0101(\mathrm{mp}-20)$

$S:$ Water Solubility, $\mathrm{mol} / l$

$\mathrm{mp}$ : Melting point, $\left(\mathrm{mp}>20^{\circ} \mathrm{C}\right)$
Table 3 Relationships between TSA and water solubility of aromatic compounds

\begin{tabular}{lccc}
\multicolumn{1}{c}{ Chemicals } & $\begin{array}{c}\mathrm{mp} \\
\left({ }^{\circ} \mathrm{C}\right)\end{array}$ & $\begin{array}{c}\text { TS A } \\
\left(\AA^{2}\right)\end{array}$ & $\left.(\log S)_{\mathrm{mp}}{ }^{a}\right)$ \\
\hline a. Benzene & 5.5 & 111.0 & -1.64 \\
b. Indan & $<25$ & 153.5 & -3.03 \\
c. Naphthalene & 80.2 & 157.4 & -3.51 \\
d. Acenaphthene & 96.2 & 177.3 & -3.89 \\
e. Biphenyl & 71.0 & 192.8 & -3.89 \\
f. Fluorene & 116.0 & 196.1 & -4.02 \\
g. Phenanthrene & 101.0 & 200.2 & -4.40 \\
h. Anthracene & 216.2 & 204.9 & -4.48 \\
i. Pyrene & 156.0 & 215.8 & -4.88 \\
j. Fluoranthene & 111.0 & 220.8 & -5.05 \\
k. Triphenylene & 199.0 & 239.8 & -5.00 \\
1. Chysene & 255.0 & 244.2 & -5.78 \\
m. Naphthacene & 357.0 & 251.2 & -5.40 \\
n. Benzo[ $a$ ]anthracene & 156.0 & 251.9 & -5.92 \\
o. Benzo[ $e$ ]pylene & 178.0 & 248.9 & -6.20 \\
p. Perylene & 277.0 & 254.8 & -6.31 \\
q. Benzo[ghi]perylene & 277.0 & 269.8 & -6.52 \\
a) S=Solubility (mol/l), & & \\
& &
\end{tabular}

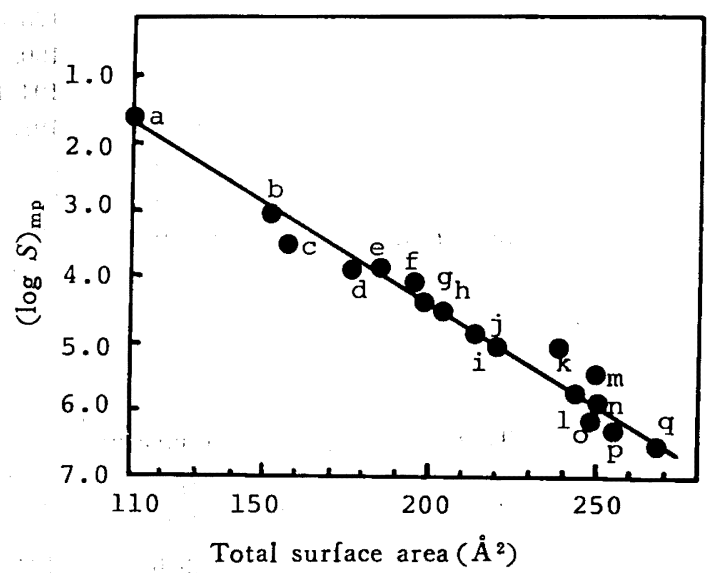

Fig. 7 Relationship between TSA and water solubility

a : Benzene, b : Indan, c : Naphthalene,

d : Acenaphthene, c : Biphenyl, f : Fluorene,

$\mathrm{g}$ : Phenanthrene, $\mathrm{h}:$ Anthracene, i : Pyrene,

j: Fluoranthene, k: Triphenylene, 1 : Chrysene,

$\mathrm{m}:$ Naphthacene, $\mathrm{n}:$ Benzo $[a]$ anthracene,

o: Benzo[ $e]$ pyrene, p : Perylene,

q. : Benzo[ghi]perylene

$(\log S)_{\mathrm{mp}}=\log S-0.0099(\mathrm{mp}-25)$

$\mathrm{mp}$ : Melting point, $\left(\mathrm{mp}>25^{\circ} \mathrm{C}\right)$

関係を調べたところ、式(7)および因 7 に示すよらな結果が得ら れた。

$$
\begin{aligned}
& (\log S)_{\mathrm{mp}}=1.485-0.0293 \text { TSA, } r=0.977, n=17 \\
& (\log S)_{\mathrm{mp}}=\log S+0.0099(\mathrm{mp}-25)
\end{aligned}
$$

8) C. Sutton, J.A. Calder, J. Chem. Eng. Data, 20, $320(1975)$.

9) Y.B. Tewari, M. M. Miller, S.P. Wasik, D. E. Marlire, ibid., 27, 451(1982). 
Table 4 Comparison of measured values with predicted values by TSA of alkylbenzene naphthalene and anthracene $\left(25^{\circ} \mathrm{C}\right)$

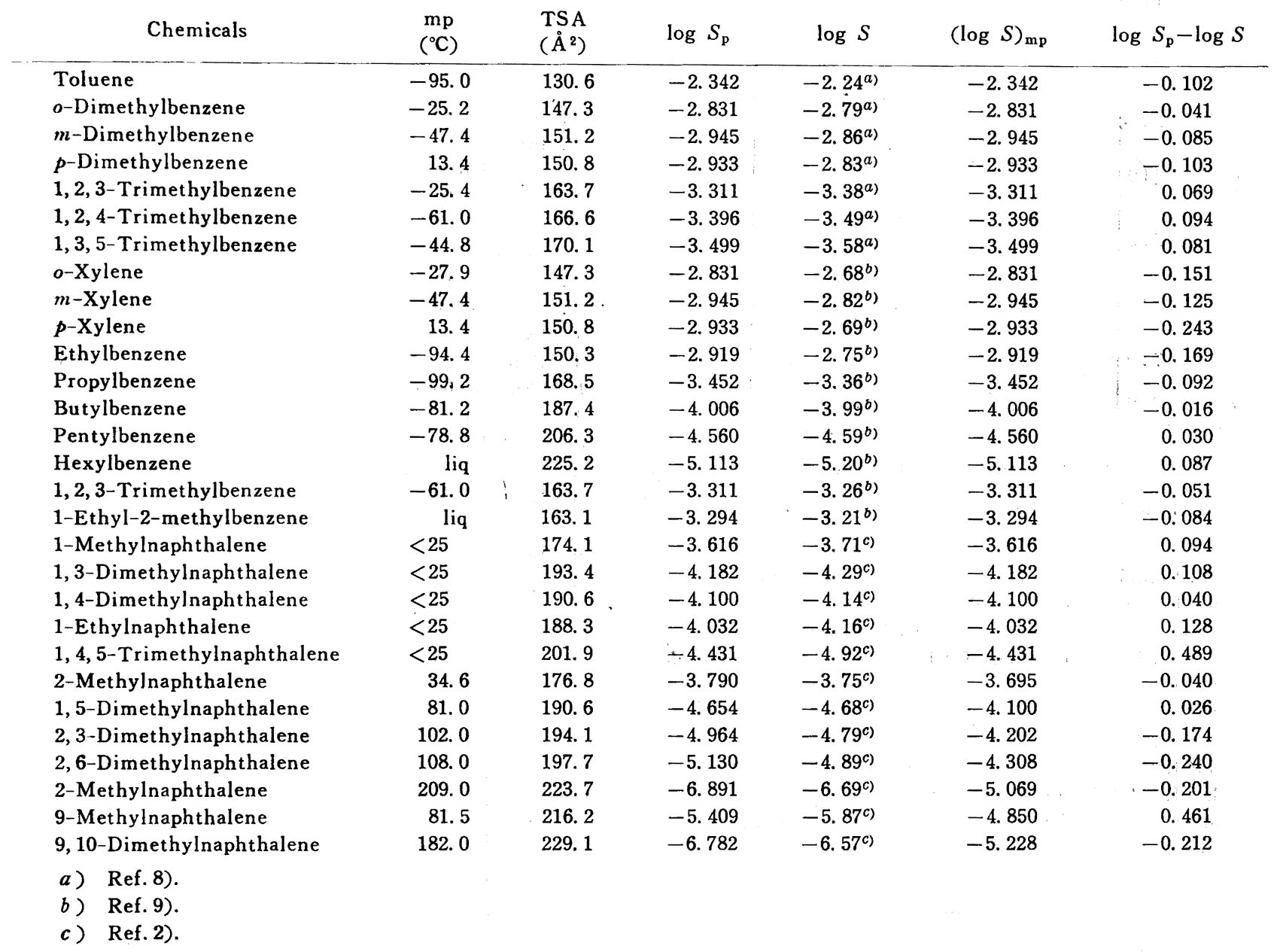

Table 5 Comparison of measured value with predicted values by TSA of benzyl halides $\left(25^{\circ} \mathrm{C}\right)$

\begin{tabular}{|c|c|c|c|c|c|c|}
\hline Chemicals & $\begin{array}{c}\mathrm{mp} \\
\left({ }^{\circ} \mathrm{C}\right)\end{array}$ & $\begin{array}{l}\text { TSA } \\
\left(\AA^{2}\right)\end{array}$ & $\log S_{\mathrm{p}}$ & $\log S$ & $(\log S)_{\mathrm{mp}}$ & $\log S_{\mathrm{p}}-\log S$ \\
\hline Chlorobenzene & -45.6 & 127.9 & $-2.262^{b)}$ & $-2.37^{b)}$ & -2.262 & 0.108 \\
\hline$o$-Dichlorobenzene & -17.0 & 143.3 & $-2.714^{b)}$ & $-3.02^{b)}$ & -2.714 & 0.306 \\
\hline Fluorobenzene & $<25$ & 114.6 & -1.873 & $-1.79^{a)}$ & -1.873 & -0.083 \\
\hline$o-$ Difluorobenzene & $<25$ & 117.8 & -1.967 & $-2.00^{a)}$ & -1.967 & 0.033 \\
\hline$m$-Difluorobenzene & $<25$ & 117.8 & -1.967 & $-2.00^{a)}$ & -1.967 & 0.033 \\
\hline$p$-Difluorobenzene & $<25$ & 118. 2 & -1.978 & $-1.97^{a)}$ & -1.978 & -0.008 \\
\hline Bromobenzene & -31.0 & 134. 3 & -2.450 & $-2.64^{a)}$ & -2.450 & 0.190 \\
\hline$o$-Dibromobenzene & 6.7 & 153.5 & -3.013 & $-3.50^{a)}$ & -3.013 & 0.487 \\
\hline$m$-Dibromobenzene & -7.0 & 156.8 & -3.109 & $-3.38^{a)}$ & -3.109 & 0.271 \\
\hline Iodobenzene & $<25$ & 142.8 & -2.699 & $-2.95^{a)}$ & -2.699 & 0.251 \\
\hline 1,2,3-Trichlorobenzene & 52.6 & 158.7 & $-3.488^{b)}$ & $-4.11^{b)}$ & -3.165 & 0.622 \\
\hline $1,3,5$-Trichlorobenzene & 68.4 & 162.9 & $-3.718^{b)}$ & $-4.62^{b)}$ & -3.288 & 0.902 \\
\hline $1,2,3,5$-Tetrachlorobenzene & 54.5 & 176. 1 & $-4.017^{b)}$ & $-5.00^{b)}$ & -3.675 & 0.983 \\
\hline $1,2,4,5$-Tetrachlorobenzene & 140.0 & 175.7 & $-4.852^{b)}$ & $-5.84^{b)}$ & -3.663 & 0.988 \\
\hline Pentachlorobenzene & 86.0 & 188. 9 & $-4.704^{b)}$ & $-6.00^{b)}$ & -4.050 & 1. 296 \\
\hline$p$-Dibromobenzene & 89.4 & 157.7 & -3.770 & $-4.07^{a)}$ & -3.136 & 0.300 \\
\hline 1,2,4-Tribromobenzene & 44.0 & 176. 8 & -3.883 & $-4.50^{a)}$ & -3.695 & 0.617 \\
\hline $1,2,5$-Tribromobenzene & 122.0 & 179.3 & -4.728 & $-5.60^{a)}$ & -3.768 & 0.872 \\
\hline $1,2,4,5$-Tetrabromobenzene & 182.0 & 190.0 & -5.636 & $-6.98^{a)}$ & -4.082 & 1. 344 \\
\hline$o$-Diiodobenzene & 27.0 & 167.6 & -3.446 & $-4.24^{a)}$ & -3.426 & 0.794 \\
\hline$m$-Diiodobenzene & 40.0 & 173. 4 & -3.745 & $-4.57^{a)}$ & -3.596 & 0.825 \\
\hline
\end{tabular}

$m$-Diiodobenzene

a) Ref. 1).

b) At $20^{\circ} \mathrm{C}$. 
Table 6 Comparison of measured values with predicted values by TSA of $\mathrm{PCBs}\left(25^{\circ} \mathrm{C}\right)$

\begin{tabular}{|c|c|c|c|c|c|c|}
\hline Chemicals & $\begin{array}{l}\mathrm{mp} \\
\left({ }^{\circ} \mathrm{C}\right)\end{array}$ & $\begin{array}{l}\text { TSA } \\
\left(\AA^{2}\right)\end{array}$ & $\log S_{\mathrm{p}}$ & $\log A^{a)}$ & $(\log S)_{\mathrm{mp}}$ & $\log S_{\mathrm{p}}-\log S$ \\
\hline Biphenyl & -0.5 & 192.8 & -4.164 & -4.32 & -4.164 & 0.156 \\
\hline $3 \mathrm{CBP}^{b)}$ & $<25$ & 210.1 & -4.671 & -4.16 & -4.671 & -0.511 \\
\hline $25 \mathrm{CBP}$ & $<25$ & 226.1 & -5.140 & -5.59 & -5.140 & 0.450 \\
\hline $2 \mathrm{CBP}$ & 34.0 & 208. 8 & -4.722 & -4.66 & -4.633 & -0.062 \\
\hline $4 \mathrm{CBP}$ & 77.7 & 209.5 & -5.175 & -5.32 & -4.653 & 0.145 \\
\hline $22^{\prime} \mathrm{CBP}$ & 61.0 & 224.4 & -5.446 & -5.45 & -5.090 & 0.004 \\
\hline $24^{\prime} \mathrm{CBP}$ & 43.0 & 225.9 & -5.312 & -5.56 & -5.134 & 0.248 \\
\hline $44^{\prime} \mathrm{CBP}$ & 149.0 & 226.5 & -6.379 & -6.60 & -5.151 & 0.221 \\
\hline $22^{\prime} 5 \mathrm{CBP}$ & 44.0 & 241.7 & -5.785 & -5.61 & -5.597 & -0.175 \\
\hline $244^{\prime} \mathrm{CBP}$ & 57.0 & 242.5 & -5.937 & -6.00 & -5.620 & 0.063 \\
\hline $245 \mathrm{CBP}$ & 78.0 & 240.8 & -6.095 & -6.44 & -5.570 & 0.345 \\
\hline $344^{\prime} \mathrm{CBP}$ & 88.0 & 241.9 & -6.227 & -7.23 & -5.603 & 1.003 \\
\hline $22^{\prime} 35 \mathrm{CBP}$ & 47.0 & 257.0 & -6.263 & -6.24 & -6.045 & -0.023 \\
\hline $2345 \mathrm{CBP}$ & 92.0 & 254.2 & -6.626 & -7.18 & -5.963 & 0.554 \\
\hline $33^{\prime} 44^{\prime} \mathrm{CBP}$ & 180.0 & 257.3 & -7.589 & -8.59 & -6.054 & 1. 001 \\
\hline $22^{\prime} 345 \mathrm{CBP}$ & 100.0 & 269.8 & -7.163 & -7.52 & -6.420 & 0.357 \\
\hline $22^{\prime} 345^{\prime} \mathrm{CBP}$ & 112.0 & 272.0 & -7.346 & -7.86 & -6.485 & 0.514 \\
\hline $22^{\prime} 346 \mathrm{CBP}$ & 100.0 & 270.4 & -7.181 & -7.43 & -6.438 & 0.249 \\
\hline $22^{\prime} 455^{\prime} \mathrm{CBP}$ & 77.0 & 271.4 & -6.982 & -7.89 & -6.467 & 0.908 \\
\hline $23456 \mathrm{CBP}$ & 124.0 & 268.2 & -7.353 & -7.68 & -6.373 & 0.327 \\
\hline $22^{\prime} 33^{\prime} 44^{\prime} \mathrm{CBP}$ & 150.0 & 284.8 & -8.098 & -8.92 & -6.860 & 0.822 \\
\hline $22^{\prime} 33^{\prime} 45 \mathrm{CBP}$ & 85.0 & 282.8 & -7.395 & -8.62 & -6.801 & 1. 225 \\
\hline $22^{\prime} 33^{\prime} 56 \mathrm{CBP}$ & 100. 0 & 284.8 & -7.603 & -8.45 & -6.860 & 0.847 \\
\hline $22^{\prime} 44^{\prime} 55^{\prime} \mathrm{CBP}$ & 103.0 & 286.3 & -7.676 & -8.48 & -6.904 & 0.804 \\
\hline $22^{\prime} 44^{\prime} 66^{\prime} \mathrm{CBP}$ & 114.0 & 289.7 & -7.884 & -8.60 & -7.003 & 0.716 \\
\hline $22^{\prime} 34^{\prime} 55^{\prime} 6 \mathrm{CBP}$ & 149.0 & 303.3 & -8.630 & -8.81 & -7.402 & 0.180 \\
\hline $22^{\prime} 33^{\prime} 44^{\prime} 55^{\prime} \mathrm{CBP}$ & 159.0 & 315.5 & -9.086 & -9.20 & -7.759 & 0.114 \\
\hline $22^{\prime} 33^{\prime} 55^{\prime} 66^{\prime} \mathrm{CBP}$ & 162.0 & 321.9 & -9.303 & -9.38 & -7.947 & 0.077 \\
\hline $22^{\prime} 33^{\prime} 44^{\prime} 55^{\prime} 6 \mathrm{CBP}$ & 206.0 & 329.4 & -9.958 & -9.62 & -8.166 & -0.338 \\
\hline Deca CBP & 305.0 & 343.1 & -11.340 & -10.49 & -8.568 & -0.850 \\
\hline
\end{tabular}

a) Ref. 4).

b) CBP : Chlorobiphenyl.

この式(7)を芳香族化合物の水への溶解度の予測式として, ア ルキルベンゼソ，ナフタレンおよびアントラセン，ハ口ゲン化べ ンゼン, $\mathrm{PCB}$ など, 80 種類の物質について TSA と $(\log S)_{\mathrm{mp}}$ を算出し，ついで式(8)により融点による補正を行ない，水への 溶解度の子測值 $S_{\mathrm{p}}$ の対数值を求めた。これらの結果は，表 4〜 6 に示した。

また，水への溶解度の実測值と予測值との比較を図 8 に示し た。

水への溶解度の予测値は，水への溶解度が低い物質ほど奖测値 より高くなる傾向がある。これを䁂換基別にみると，80種類の 化合物中，比較的水溶解度の高いメチル基置換ベンゼンでは実測 值と予測值とはよく一致しているが，それより水への溶解度が低 いn-アルキル基置換ナフタレンおよび $n$-アルキル基置換アント ラセンでは，メチル基置換ベンゼンにくらべ実測值と予測值との 差が多少大きくなる（表 4)。ハロゲン化ベンゼンは，水への溶 解度が比較的高いものから低いものまで広籍围にわたっている が，このらち，水への溶解度の高い物質では実測値と予測値とは ほほ等しい值が得られているものの, 水への溶解度が低いペンタ クロロベンゼン拈よび 1, 2, 4, 5-テトラブロモベンゼンでは, 実測 值の 20 倍と 22 倍という結果を得た（表 5 )。PCB においても同 様に，水への溶解度の低い物質では，実測值より予测值が高くな る傾向があり，表 6 にも見られるように $\log S$ が -7.0 以下の

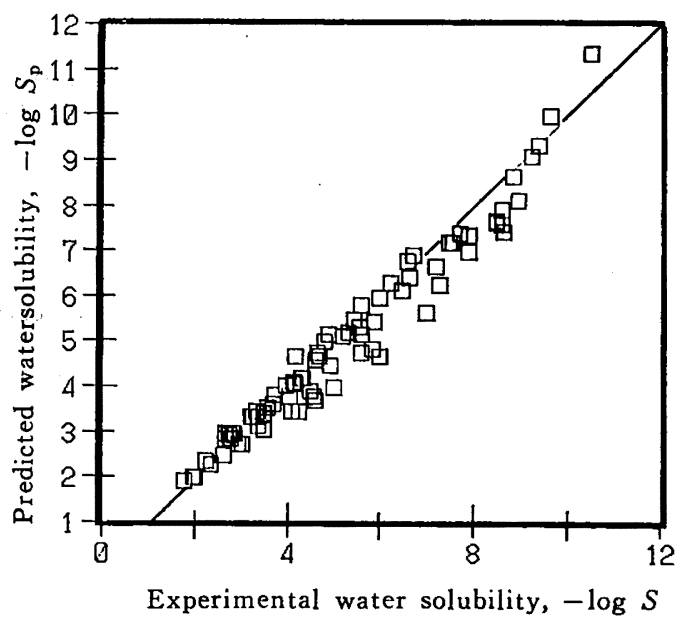

Fig. 8 Comparison of predicted and experimental water solubilities

物質では, $\log S_{\mathrm{p}}-\log S$ が1 以上となる物質がある。このよう に，疎水性置換基をすつ化合物では，水への溶解度が低い物質は そ， 実测值と予測值の差が大きくなる傾向がある。その原因の一 つとして，水への溶解度の測定に問題があると考えられる。たと えば, PCB の Deca CBP の水への溶解度は, $3.23 \times 10^{-11} \mathrm{~mol} / l$ 
$(\log S=-10.49)$ ときわめて低く，この物質の水への溶解度を 正確に測定することは難しい、しかしながら， PCB の $22^{\prime} 33^{\prime} 55^{\prime}$

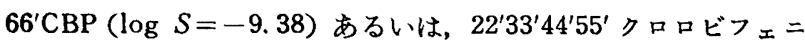
ール $(\log S=-9.20)$ のように低水溶解度であるにもかかわら ず, 実測値の 1.2 倍あるいは, 1.3 倍で予测できたことは，むし ろ例外であると考兄いる（表 6 ）。

以上の結果から，芳香族化合物の水への溶解度の実測值の対数 值が -7.0 以下の物質の場合, 実測值と予测值の差 $\left(\log S_{\mathrm{p}}-\log \right.$ $S)$ が 1.0 以上となる物質もあるが，大部分は，TSA を求め, 式 ( 7 )の水への溶解度の予測式に代入することにより, 芳香族化 合物の全般にわたる水への溶解度の予測が可能であると考えられ る。

\section{5 結 語}

Monte Carlo 法による分子表面積の算定では，分子を構成す る各原子の表面に均一に 510 個の点を与え, そのそれぞれが隣接 する原子の内部に位固しないことを判定条件として，条件を満た す点の数を数え, 原子表面に与えた点の総数に対する相対頻度を
求めて分子表面積を算出する。得られたTSA と水への溶解度の 実测值との相関式によって，水への溶解度を予測することができ るが，比較的水への溶解度が高い物質 $\left(10^{-7} \mathrm{~mol} / l\right.$ 以上) では, 実測値は予測值の 0. 4 10 倍以内であるが，これよりも水への溶 解度が低い物質 $\left(10^{-7} \mathrm{~mol} / l\right.$ 以下) では，実測值の 22 倍となる ものが，80 種類の芳香族化合物中に 1 種類存在した。これらを 置換基別にみると， 29 種類の $n$-アルキル基を有する芳香族化合 物の予測值は，実測值の $0.6 \sim 3$ 倍であり， 八ロゲン化ベンゼン では，21種類の物質中，水への溶解度の低い $1,2,4,5$-テトラブ ロモベンゼンが 22 倍, ペンタクロロベンゼンが 20 倍となった が，ほかの物質は，0.8〜10 倍の籁囲となった。また，PCB 30 種類の化合物では， $0.1 \sim 17$ 倍という結果を得た。以上の結果か ら, 水への溶解度が $10^{-11} \sim 10^{-2} \mathrm{~mol} / l$ といら広範围な物質の子 测值は，0.1〜10 倍の範囲で予湘できるものと考える。

本研究を進めるにあたり，有益な御助言をいたたいた磨応義熟 大学理工学部教授佐藤 力氏に梁く謝意を表明いたします。

（1985 年 4 月, 日本化学会第 49 春季年会に打いて一部を発表）

\title{
Prediction of Solibility of Aromatic Compounds in Water by Using Total Molecular Surface Area
}

\author{
Hideko KISHI*, Masayuki NaKamura and Yoshikazu Hashimoto \\ Department of Applied Chemistry, Faculty of Science and Technology, Keio University; \\ Hiyoshi, Yokohama-shi 223 Japan
}

To estimate the solubility of a compound in water from its total surface area(TSA) of a molecule, a modified Monte Carlo method was applied to the determination of the molecular surface area. About 500 points were distributed equally on the surface of each atom of molecule, and the number of points over the molecular surface were counted to calculate TSA of the molecule. The TSA calculated by this method had a good correlation with experimental water solubilities. Using an equation formulated from this relationship, the solubilities of $80 \mathrm{kinds}$ of hydrophobic aromatic compounds were predicted and compared with experimental values. For 29 alkylbenzenes, the ratios of predicted water solubilities to the experimental ones were found to be $0.6 \sim 3$, but this ratios become $0.1 \sim 10$ for all the 80 compounds investigated. In general, estimated water solubilities were smaller than the experimental values. 